\title{
Homeschooling Implementation: Indonesian Parents' Experience During The COVID-19 Pandemic
}

\author{
Nurussakinah Daulay 1, Wiwin Hendriani 2, Haerani Nur 3, Sayidah Aulia'ul \\ Haque 4
}

DOI: $10.35445 /$ alishlah.v13i1.390

\section{Article Info}

Keywords:

Homeschooling

Covid-19

Pandemic

Parent

Children

Kata kunci:

Sekolah dari rumah

Covid-19

Pandemi

Orang tua

Anak

\section{Abstract}

This study aimed to explore parents' difficulties and efforts in implementing homeschooling during the Covid-19 pandemic from diverse regions in Indonesia. The research was conducted twice, namely three weeks after the enforcement of Large-Scale Social Restriction (PSBB) and ten months after that. The total participants involved were 385 parents in the first study and 105 parents in the second study in this exploratory study. The method used in this study was descriptive qualitative with the data collection using two open-ended questions online. The result showed that schools that had implemented online learning applications before the pandemic would make the parents, teachers, and students easier in facing homeschooling challenges. The school that never implemented online applications before the pandemic made the parents, teachers, and students notice overwhelmed by the challenges of homeschooling. Parents both actively and passively perform how to overcome homeschooling difficulties.

\begin{abstract}
Abstrak
Penelitian ini bertujuan untuk mengeksplorasi kesulitan dan usaha-usaha yang orang tua lakukan dalam pelaksanaan sekolah dari rumah selama pandemi covid-19 dari berbagai wilayah di Indonesia. Penelitian ini dilakukan sebanyak dua kali, yakni pada tiga minggu setelah diberlakukannya pembatasan sosial berskala besar (PSBB) dan sepuluh bulan setelahnya. Partisipan penelitian sebanyak 385 orang tua pada penelitian pertama dan sebanyak 105 orang tua pada penelitian kedua telah terlibat dalam studi eksplorasi ini. Metode penelitian yang digunakan adalah kualitatif dengan pengumpulan data menggunakan dua pertanyaan terbuka secara online. Hasil penelitian terdapat dua tema pelaksanaan sekolah dari rumah, yakni: 1) sekolah yang sebelum kemunculan pandemi sudah menerapkan aplikasi belajar online sehingga sebagian besar orang tua, guru dan siswa lebih mudah beradaptasi terhadap tantangan sekolah dari rumah; 2) sekolah yang sebelum pandemi belum pernah
\end{abstract}

\footnotetext{
${ }^{1}$ Universitas Islam Negeri Sumatera Utara, Medan, Indonesia

Email: nurussakinah@uinsu.ac.id

2 Universitas Airlangga, Surabaya, Indonesia

Email: wiwin.hendriani@psikologi.unair.ac.id

3 Universitas Negeri Makasar, Indonesia

Email: haerani.nur@unm.ac.id

4 Universitas 17 Agustus 1945, Surabaya, Indonesia

Email: sayidahaulia@untag-sby.ac.id
} 
menerapkan aplikasi online maka akan terlihat orang tua, guru dan siswa kewalahan terhadap tantangan sekolah dari rumah. Cara mengatasi kesulitan sekolah dari rumah dilakukan orang tua baik secara aktif maupun pasif.

\section{INTRODUCTION}

Coronavirus disease, known as COVID-19, is a new type of virus easily transmitted and can quickly infect the respiratory system, causing death. The World Health Organization (WHO) then declared it a global pandemic on March 11, 2020 (WHO, 2020). Anticipate the increasing number of deaths and minimize infection from this epidemic, each country implements rules for its people to work and study at home (WHO, 2020). Various studies continue to be of interest to reveal the impact of Covid-19 on aspects of human life, especially the effect on the educational context in the form of temporary closings of schools to universities. Learning, which initially took place face-to-face, turned into online learning. Teachers and students were not ready to anticipate changes that occurred suddenly and demanded to adapt to this situation (Murphy, 2020). Changes in the learning model that appeared suddenly did not escape various challenges. Especially for students, teachers, and parents impact of online learning for students includes experiencing emotional changes such as stress (King et al. 2020; Wang, 2020); anxious (Gritsenko et al. 2020); technological and internet challenges (Almaiah et al. 2020; Zhu \& Liu, 2020); decreased mental health and motivation (Raaper \& Brown, 2020). And if this lasts any longer, then it has the opportunity to reduce the competence of human resources (Azorin, 2020). The teacher has challenges using internet technology as the primary tool in teaching (Schleicher, 2020). It includes weak internet access (Kalloo et al. 2020), teachers do not have adequate facilities to support online learning (Flores \& Gago, 2020), and workloads that get heavier (Mercer \& Gregersen, 2020). Likewise, parents feel, the difficulty of implementing homeschooling raises the burden of care ( $\mathrm{Wu} \& \mathrm{Xu}, 2020)$; difficulty regulating emotions affects the quality of parenting (Shorer \& Leibovich, 2020); decreases mental health (Bıkmazer et al. 2020); low self-efficacy (Navarrete-Mejía et al. 2020); a loss of childcare (Patrick et al. 2020); changes in daily habits (Fiese et al. 2020); higher childcare costs during lockdown (Craig \& Churchill, 2020); and difficulty teaching children's schoolwork (Weaver \& Swank, 2020). There are several reasons parents have not been able to adapt to replace the role of teachers when children learn online at home, namely: 1) Busy parents working to make a living; 2) Parents are less able to master the technology; 3) The low level of parental education (Andrew et al. 2020).

Based on the information above proves the heavy burden on parents to take care of children during the pandemic. It is risky not only for the emotional condition of the parents and the decreasing quality of interaction and care for children but also for the child's condition. The emotional adjustment of children in this uncertain time depends on their parents' emotional state (Shorer \& Leibovich, 2020). Parents are adult figures who are always close to children. Parents' treatment of children will affect children's attitudes and behavior. Santrock (2003) states that parents are essential figures in forming children's identity, especially adolescents. The importance of parental care for children is evidenced from research that shows how anxiety that parents own decreases in children through the behavior and beliefs of the parents (Francis \& Chorpita, 2011). Prosperous parents can also be seen from the behavior of successful children (Nayana, 2013). Parental attention has a positive impact on children's interests and learning achievement (Pratiwi, 2017).

The role of parents during the pandemic has also been proven by various previous studies. Parents act as mentors, educators, carers, developers, and supervisors (Kurniati et al. 2020). The positive impact of learning from home is that parents can improve their relationships with children and can see firsthand the development of their children's ability to learn (Cahyati \& Kusuma, 2020). Parents also feel various obstacles regarding distance learning, namely low understanding of children's learning materials, difficulties in increasing children's interest in learning, limited time to accompany children because they have to work, impatience in attending to children while studying at home, lack of understanding in operating gadgets, and obstacles. Internet services (Wardani \& Ayriza, 2020); the way parents support children's learning, namely by helping the child's task difficulties, understanding children about the material they do not understand, responding well to being divisive from home (Yulianingsih et al. 2020). 
During the pandemic, the role of parents has increased. Apart from accompanying their children to school from home, parents are also required to divide their time between household work and office work for those who have careers. The importance of exploring parents' experiences with the implementation of online learning in Indonesia has been quite evident, especially revealing parents' condition in the first month after a lockdown in Indonesia. However, no research has been found examining the school experience requirements from home during large-scale social restrictions and the new normal period. Therefore, this research will explore the experiences that parents experience when they have to adapt to assist their children in learning from home in the first three weeks of implementing the PSBB and ten months after that. This study asks two questions: how was the homeschooling you run with your children during the Covid-19 outbreak, and how to overcome difficulties in implementing homeschooling?

\section{METHODS}

This study explores parents' experiences in implementing homeschooling during the first month of implementing the PSBB in all cities in Indonesia. Through a qualitative research design, it is hoped that the collected data will provide helpful information regarding the performance of homeschooling for parents. In qualitative research, it analyzed words and then grouped them into more significant understanding, such as code, category, or theme (Creswell, 2015). The first study involved 385 parents from various regions in Indonesia. Parents dominated participants with the category of early adulthood 205 (53.24\%), who live in the Java region (48.05\%). Most of them are housewives (30.9\%), with more than two children (43.89\%), and are students in elementary schools (94\%). Furthermore, in the second study, the number of participants was 104 parents, most of whom were in the early adult category (53.24\%), who lived in the Sumatra region (48.05\%). Most of the participants were housewives (30.9\%), with more than two children (43.89\%) and the status of elementary school students (94\%).

This research was conducted twice, namely: the first study, one week starting from March 24 to March 31, 2020; The second research was carried out ten months later, to be exact, January 18 to 24, 2021, by distributing an online instrument in the form of open-ended questions via Google Form and distributed to several WhatsApp groups. The online tool consisted of research objectives, work instructions, informed consent, personal data, and open-ended questions. The answers to these questions are not limited to the number of words so that participants can freely explore in response to the question. Besides, the research team also asked for the cooperation of members of the WhatsApp group to share links with their respective partners. The research participants were parents of children who were carrying out school from home, and the participants were scattered from various regions in Indonesia. The Indonesian Developmental Psychology Association supported this research.

The data were analyzed using the thematic analysis of Braun and Clarke (2006) to identify, analyze, organize, describe, and report the themes found in the data set. Through this analysis, the researcher seeks to understand and explore parents' experiences regarding the implementation of distance learning in the first month after the performance of large-scale social restrictions (PSBB) in Indonesia.

\section{FINDINGS AND DISCUSSION}

\section{Research 1}

Coding analysis was used to identify the implementation of homeschooling for parents. Researchers have identified 385 respondents' answers related to the implementation of homeschooling which is the responsibility of parents, and revealed that there are 3 themes and 10 sub-themes that were revealed from the implementation of school from home in the third week after the PSBB in Indonesia. Information can be seen in Table 1. 
Table 1. Themes of implementing homeschooling in the first three weeks of the implementation of the lockdown

\begin{tabular}{|c|c|c|c|}
\hline No & Themes & Subthemes & Frequency \\
\hline \multirow[t]{5}{*}{1.} & $\begin{array}{l}\text { The schools that have } \\
\text { implemented online }\end{array}$ & $\begin{array}{l}\text { - The school schedule from home has } \\
\text { been determined }\end{array}$ & 38 \\
\hline & applications & - Learn online through various & 43 \\
\hline & & $\begin{array}{l}\text { applications (google classroom, zoom, } \\
\text { WA group, google forms). }\end{array}$ & \\
\hline & & - The teacher provides interesting & 36 \\
\hline & & $\begin{array}{l}\text { - Children and parents adapt more } \\
\text { quickly }\end{array}$ & 21 \\
\hline \multirow[t]{5}{*}{2.} & $\begin{array}{l}\text { The schools that have } \\
\text { not implemented }\end{array}$ & $\begin{array}{l}\text { - Providing materials and assignments } \\
\text { only through the WA group }\end{array}$ & 47 \\
\hline & online applications & $\begin{array}{l}\text { - The teacher gives more assignments } \\
\text { than explanations }\end{array}$ & 52 \\
\hline & & - The material is not attractive & 63 \\
\hline & & - Less able to adapt & 31 \\
\hline & & $\begin{array}{l}\text { - Easily appear negative emotions } \\
\text { (anxiety, stress) }\end{array}$ & 21 \\
\hline 3. & The school closed & $\begin{array}{l}\text { - There is no teaching and learning } \\
\text { process }\end{array}$ & 33 \\
\hline
\end{tabular}

Overall, the implementation of homeschooling in the first three weeks of implementing the lockdown has two themes: schools that before the emergence of the pandemic have implemented online learning applications. Most parents, teachers, and students adapt more quickly to the challenges of homeschooling. On the other hand, for schools that before the pandemic had never implemented an online application, it will be seen that parents, teachers, and students are overwhelmed by the challenges of schooling from home. During the first three weeks of the lockdown, many schools were closed and did not carry out teaching and learning activities. Furthermore, to overcome the various challenges of homeschooling, there are two themes, namely active and passive (can be seen in Table 2).

Table 2. Themes overcoming difficulties in implementing homeschooling in the first three weeks of the implementation of the lockdown

\begin{tabular}{|c|c|c|c|}
\hline No & Themes & Subthemes & Frequency \\
\hline & Active & $\begin{array}{l}\text { - Get involved in children's assignments } \\
\text { (helping to find material, browsing, and } \\
\text { assignments, discussing with children, giving } \\
\text { some exercises/questions) } \\
\text { - Discuss with the teacher } \\
\text { - Set a child's the schedule/instalment } \\
\text { assignments) } \\
\text { - Be patient/sincere in helping children } \\
\text { - Bringing tutors } \\
\text { - Seek support groups } \\
\text { - Provide rewards/motivate children } \\
\text { - Complete personal assignments first then } \\
\text { complete children's assignments } \\
\text { - Share roles with husbands/siblings of } \\
\text { children }\end{array}$ & $\begin{array}{c}25 \\
27 \\
\\
36 \\
4 \\
8 \\
11 \\
15 \\
\\
21\end{array}$ \\
\hline
\end{tabular}


- Communicating with children / providing understanding to children

- Discipline

\begin{tabular}{llc}
\hline - & & 15 \\
\hline & Just accompany you without helping out & 10 \\
- Scolding the child/threatening to apply & 7 \\
- Dunishment & 59 \\
- Sleep nothing & 4 \\
- Children are left to learn on their own & 14 \\
\hline
\end{tabular}

\section{Research 2}

A total of 105 respondents' answers have been analyzed. There are 3 themes and 9 sub-themes that were revealed from the implementation of homeschooling 10 months later after the occurrence of PSBB in Indonesia. Information can be seen in Table 3.

Table 3. Themes of implementing school from home in ten months from the enactment of the lockdown

\begin{tabular}{|c|c|c|c|}
\hline No & Themes & Subthemes & Frequency \\
\hline \multirow[t]{4}{*}{1.} & $\begin{array}{l}\text { The schools that have } \\
\text { implemented online }\end{array}$ & $\begin{array}{l}\text { - The school schedule from home has } \\
\text { been determined }\end{array}$ & 10 \\
\hline & applications & $\begin{array}{l}\text { - Learn online through various } \\
\text { applications (google classroom, zoom, } \\
\text { WA group, google forms). }\end{array}$ & 54 \\
\hline & & $\begin{array}{l}\text { - The teacher provides interesting } \\
\text { material }\end{array}$ & 12 \\
\hline & & $\begin{array}{l}\text { - Children and parents adapt more } \\
\text { quickly }\end{array}$ & 29 \\
\hline \multirow[t]{5}{*}{2.} & $\begin{array}{l}\text { The schools that have } \\
\text { not implemented }\end{array}$ & $\begin{array}{l}\text { - Providing materials and assignments } \\
\text { only through the WA group }\end{array}$ & 3 \\
\hline & online applications & $\begin{array}{l}\text { - The teacher gives more assignments } \\
\text { than explanations }\end{array}$ & 4 \\
\hline & & - The material is less attractive & 11 \\
\hline & & - Less able to adapt & 38 \\
\hline & & $\begin{array}{l}\text { - Easily appear negative emotions } \\
\text { (anxiety, stress) }\end{array}$ & 49 \\
\hline
\end{tabular}

The researchers conducted another survey but with different participants to see how implementing homeschooling after 10 months because researchers had difficulty contacting participants in the first study. The contact number of each participant was not recorded. Furthermore, the researchers distributed two open-ended questions like the questions in the first study with a span of two weeks and collected as many as 105 participants. Overall, the implementation of homeschooling in 10 months after the implementation of the lockdown there are the same themes and sub-themes, it only appears that after 10 months of implementing homeschooling, parents have been able to adapt to the difficulties that have arisen, teachers also do not burden students much with assignments. The assignments and material presented are more exciting and varied. Students are also familiar with online learning. Furthermore, to overcome the various challenges of homeschooling, the themes that emerged were the same as the first research, namely active and passive themes (can be seen in Table 4). 


\begin{tabular}{|c|c|c|c|}
\hline No & Themes & Subthemes & Frequency \\
\hline 1. & Active & $\begin{array}{l}\text { - Get involved in children's assignments } \\
\text { (helping to find material, browsing, and } \\
\text { assignments, discussing with children, giving } \\
\text { some exercises/questions) } \\
\text { - Discuss with the teacher } \\
\text { - Set a child's schedule/installment } \\
\text { assignments) } \\
\text { - Be patient/sincere in helping children } \\
\text { - Bringing tutors } \\
\text { - Seek support groups } \\
\text { - } \text { Provide rewards/motivate children } \\
\text { - completing new personal assignments of } \\
\text { - Share roles with husbands/siblings of } \\
\text { children } \\
\text { - } \text { understanding to children } \\
\text { Discipline }\end{array}$ & $\begin{array}{c}8 \\
12 \\
\\
18 \\
1 \\
1 \\
3 \\
6 \\
\\
9 \\
11 \\
2\end{array}$ \\
\hline & Passive & $\begin{array}{l}\text { - Just accompany you without helping out } \\
\text { - Threatening to apply punishment } \\
\text { - Do nothing } \\
\text { - Sleep } \\
\text { - Children are left to learn on their own }\end{array}$ & $\begin{array}{l}1 \\
2 \\
3 \\
0 \\
5\end{array}$ \\
\hline
\end{tabular}

Likewise, for the theme of overcoming difficulties in implementing homeschooling in ten months from the implementation of the lockdown, it is seen that parents are more active in supporting the implementation of homeschooling. The factor of adapting to various obstacles is that the performance of school from home can be carried out well.

This study explores the implementation of homeschooling during the first three weeks after the Indonesian Government implements the rule that Indonesians must work and study at home (Ministry of Health of the Republic of Indonesia, 2020) and how it will be implemented ten months later. Since the Covid-19 pandemic, formal learning previously carried out conventionally in schools has changed because it has to be carried out at home. This requires the adaptability of parents, teachers, and children and cooperation between parents and schools so that homeschooling runs optimally. Adaptation helps parents to accept difficulties more quickly during a pandemic (Tarigan \& Hidayati, 2020), student adaptation helps accelerate online-based academic systems (Dulkiah et al. 2020), teacher adaptation by digging up information related to online learning through internet media such as google and youtube, and discuss with colleagues (Lindawati \& Rachman, 2020).

The first study results proved that most of the respondents revealed that homeschooling was less than optimal. Many factors influence it. This is evident from the effects of open-ended questions that there is important information related to the implementation of homeschooling. The critical point that needs to be considered in this first study is that schools that have previously implemented online applications (such as e-learning) will be more adaptable when learning is done completely online such as during this pandemic, and quickly adjust to various other online learning applications ( such as: google classroom, zoom). This is in line with various studies that prove the importance of knowing information technology in learning during a pandemic (Khasanah et al. 2020), online applications for elementary school students effectively use google classrooms and zoom applications (Astini, 2020), the application of online learning has a positive impact. as a trigger for the acceleration of the digital transformation process of education in Indonesia (Latip, 2020)

However, the fact is that most schools in Indonesia have not implemented learning through online applications. When this pandemic is present, it is unknown when it will end, resulting in 
difficulties for some parents, teachers, and children in adapting to online learning, such as mastery of technology are still lacking. (Purwanto et al. 2020); the ability of teachers who are not familiar with the application (Padli \& Rusdi, 2020); no preparation of rules related to the implementation of online learning has not been found (Hamdani et al. 2020); lack of availability of facilities and infrastructure (Pangondian et al. 2019); until the emergence of boredom for students due to the large number of assignments given (Umar \& Nursalim, 2020).

Even so, several schools in Indonesia before the arrival of the pandemic, apart from face-toface teaching and learning, it turns out that schools have socialized online learning using one application (such as e-learning, WA group). This condition affected homeschooling during the pandemic, especially when large-scale social restrictions (PSBB) took place for three months in Indonesia. The positive impact is that children feel comfortable and adaptable when given materials and assignments through online applications. The teacher also experiences this adaptation condition. It is easy for teachers to prepare material content in the form of power points, videos, and this material to be interesting for children. Research conducted by (Jamaluddin et al. 2020) also confirms that as many as $60 \%$ of research respondents are accustomed to implementing online learning. It has a positive effect on the ease of understanding and online tutoring.

The difficulty of going to homeschooling is not only experienced in Indonesia. The previous research also confirmed that in several countries, students in schools experienced problems in dealing with online learning, such as internet network problems that will affect the quality of education in Malaysia (Nasri et al. 2020). The psychoemotional development of students is not optimal because of the lack of meetings with friends to travel together, do outdoor activities, which raises anxiety for students in the Philippines (Cleofas, 2020). Furthermore, research in Vietnam reports that students are given convenience in supporting online learning by reducing school fees and internet access (Dinh \& Nguyen, 2020; Pham \& Ho, 2020). Research reports in China prove that there is student dissatisfaction with online learning (Tang et al. 2020).

After ten months of homeschooling, the second study results found that conditions were almost the same at the start of the pandemic. The main obstacle found was that homeschooling was related to the weak internet network and the psychological state of students who were required to be able to adapt during the pandemic crisis, causing various things, such as stress (Firang, 2020), anxiety (Cao et al. 2020), low motivation to learn. (Fitriani et al. 2020). The difference from the first study was that a survey conducted ten months later showed that parents could adapt to various sources of stress that were present, especially the challenges of going to homeschooling. Another exciting thing from the results of the second research survey is that parents and children have coping strategies that can minimize various sources of stress. For parents, one of the most commonly found coping is to be patient. Patience is defined as the ability to remain calm during times of difficulty, frustration, or suffering (Schnitker, 2012). The importance of patience has also been proven by various previous studies, including creating well-being (Chakhssi et al., 2018), reduce depression (Heslin, Elixhauser, \& Steiner, 2012), fortification against suicidal ideation (Hashemi et al. 2018). Likewise, the coping strategy developed for children is to pay in instalments to complete school assignments, not accumulate and tell stories with the family about the problems. It can be seen that the coping strategies used by children can be grouped into problem-focused coping, which is a strategy in overcoming issues by changing the source of the problem and increasing the resources they have (Lazarus \& Folkman, 1984). The source of students' issues in distance learning is the resources they have, namely self-confidence to complete assignments from the teacher.

Pandemic conditions that are not known when will end must be addressed positively so that every human being remains mentally healthy so that the right coping strategies are needed. Coping is an individual process that tries to manage current demands (both demands from the individual itself and requests from the environment) and the resources that exist within them that are used in dealing with stressful situations (Lazarus \& Folkman, 1984 in Sarafino \& Smith, 2014). Coping is a balancing factor for individual efforts to maintain their adjustment during stressful situations (Billing \& Moos, 1984 in Daulay, 2020).

The benefit of a coping strategy during a pandemic is adapting to the difficulties that come at this time of crisis. Various studies have also proven the benefits of coping during a pandemic, including Kar et al. (2020), demonstrated that mild distress during a pandemic could be pursued by reassuring oneself, strengthening support, and relaxing, so when someone experiences severe distress. It is advisable to consult professionals. Furthermore, Park et al. (2020) revealed that during a pandemic, a person experiences stress due to the spread of the disease and uncertainty over 
changes to daily routines. Some things that are suggested should be able to do active coping and get emotional support. I told that things that are suggested should be able to do active coping and get emotional support and religious coping. Likewise, research conducted by Baloran (2020) reports that for students, it is certainly not easy to adapt to situations that have never been felt, students experience increased anxiety when the lockdown takes place, and coping strategies are needed to strengthen themselves.

\section{CONCLUSION}

This research can reveal the implementation of homeschooling during the lockdown period and the new normal period. After conducting a longitudinal study, several differences in the implementation of distance learning were found; namely, the habitual factor in using online media learning is faster adapting to learning difficulties from home during the pandemic. When parents can adopt, it will affect their ability to manage negative emotions better. Parents' efforts vary in minimizing these difficulties, namely through active coping strategies, and many parents have found some who prefer to be silent and not trying (passive). This study still has limitations, among others, that the respondents of the study between the first study and the second study were not the same parents. The factors causing the contact number of the respondent were not recorded, so it was difficult for researchers to contact the respondents in the first study. Furthermore, filling out the survey was carried out using the online system to be one of the causes of the uneven distribution of data. The researcher did not know how the respondent was and confirmed that filling out the online survey was the child's parents. The implication conveyed from the results of this study is the importance of stress management in addressing homeschooling related to coping strategies. The weight of the barriers that parents bear during the pandemic impacts the difficulties of parents and teachers. This source of stress can be minimized.

\section{REFERENCES}

Almaiah, M. A., Al-Khasawneh, A., \& Althunibat, A. (2020). Exploring the critical challenges and factors influencing the E-learning system usage during COVID-19 pandemic. Education and Information Technologies, 1. https://doi.org/10.1007/s10639-020-10219-y

Andrew, A., Cattan, S., Dias, M. C., Farquharson, C., Kraftman, L., Krutikova, S., \& Sevilla, A. (2020). How are mothers and fathers balancing work and family under lockdown"'?". Institute for Fiscal Studies Briefing Note BN29O.

Astini, N. K. S. (2020). Pemanfaatan teknologi informasi dalam pembelajaran tingkat sekolah dasar pada masa pandemi covid-19. Lampuhyang,11(2), 1325. https://doi.org/10.47730/jurnallampuhyang.v11i2.194

Azorin, C. (2020). Beyond COVID-19 supernova: Is another education coming? Journal of Professional Capital and Community. Terbit pertama online (hlm. 1-10). https://doi.org/10.1108/JPCC-05-2020-0019

Baloran, E. T. (2020). Knowledge, Attitudes, Anxiety, and Coping Strategies of Students during COVID-19 Pandemic. Journal of Loss and Trauma, 1-8. https://doi.org/10.1080/15325024.2020.1769300

Biggerstaff, D., \& Thompson, A. R. (2008). Interpretative phenomenological analysis (IPA): A qualitative methodology of choice in healthcare research. Qualitative Research in Psychology, 5(3), 214-224. https://doi.org/10.1080/14780880802314304

Bıkmazer, A., Kadak, M. T., Görmez, V., Doğan, U., Aslankaya, Z. D., Bakır, F., ... \& Karayağmurlu, A. (2020). Parental psychological distress associated with COVID-19 outbreak: A large-scale multicenter survey from Turkey. International Journal of Social Psychiatry, https://doi.org/10.1177/0020764020970240

Braun, V., \& Clarke, V. (2006). Using thematic analysis in psychology. Qualitative research in psychology, 3(2), 77-101.

Cao, W., Fang, Z., Hou, G., Han, M., Xu, X., Dong, J., \& Zheng, J. (2020). The psychological impact of the COVID-19 epidemic on college students in China. Psychiatry Research, 287, 1-5. https://doi.org/10.1016/j.psychres.2020.112934 
Chakhssi, F., Kraiss, J. T., Sommers-Spijkerman, M., \& Bohlmeijer, E. T. (2018). The effect of positive psychology interventions on well-being and distress in clinical samples with psychiatric or somatic disorders: A systematic review and meta-analysis. BMC Psychiatry, 18, 211. https://doi.org/10.1186/s12888-018-1739-2

Cleofas, J. V. (2020). Life Interruptions, Learnings and Hopes among Filipino College Students during COVID-19 Pandemic. Journal of Loss and Trauma, 1-9. https://doi.org/10.1080/15325024.2020.1846443

Craig, L., \& Churchill, B. (2020). Dual-earner parent 'couples' work and care during COVID-19. Gender, Work, \& Organization. https://doi.org/10.1111/gwao.12497

Creswell, J. (2015). Educational research, planning, conducting, and evaluating quantitative and qualitative. Pearson Education, Inc.

Daulay, N. (2020). Psikologi pengasuhan bagi orang tua dari anak-anak dnegan gangguan perkembangan saraf (neurodevelopmental disorders). Jakarta: Prenadamedia.

Dinh, L. P., \& Nguyen, T. T. (2020). Pandemic, social distancing, and social work education: 'Students' satisfaction with online education in Vietnam. Social Work Education, 39(8), 10741083. https://doi.org/10.1080/02615479.2020.1823365

Dulkiah, M., Nurmawan, N., Rohmana, J. A., \& Rahman, A. S. (2020). Adaptasi mahasiswa dalam penggunaan media online sebagai dampak wabah Covid-19. Digital Library UIN Sunan Gunung Djati.

Fiese, B. H., Tomcho, T. J., Douglas, M., Josephs, K., Poltrock, S., \& Baker, T. (2002). A review of 50 years of research on naturally occurring family routines and rituals: Cause for celebration? Journal of Family Psychology, 16(4), 381-390. https://doi.org/b39mcb

Firang, D. (2020). The impact of COVID-19 pandemic on international students in Canada. International Social $\quad$ Work, 63(6), https://doi.org/10.1177/0020872820940030

Fitriyani, Y., Fauzi, I., \& Sari, M. Z. (2020). Motivasi belajar mahasiswa pada pembelajaran daring selama pandemik covid-19. Jurnal Kependidikan: Jurnal Hasil Penelitian dan Kajian Kepustakaan di Bidang Pendidikan, Pengajaran dan Pembelajaran,6(2), 165-175. https://doi.org/10.33394/jk.v6i2.2654.

Flores, M.A., \& Gago, M. (2020). Teacher education in times of COVID-19 pandemic in Portugal: national, institutional, and pedagogical responses. Journal of Education for Teaching, 1-10. https://doi.org/10.1080/02607476.2020.1799709

Francis, S. E., \& Chorpita, B. F. (2011). Parental Beliefs About Child Anxiety as a Mediator of Parent and Child Anxiety. Cogn Ther Res, 35, 21-29. http://dx.doi.org/10.1007/s10608-009-92559

Gritsenko, V., Skugarevsky, O., Konstantinov, V., Khamenka, N., Marinova, T., Reznik, A., \& Isralowitz, R. (2020). COVID 19 Fear, Stress, Anxiety, and Substance Use Among Russian and Belarusian University Students. International Journal of Mental Health and Addiction, 1. https://doi.org/10.1007/s11469-020-00330-z

Hamdani, A. R., \& Priatna, A. (2020). Efektifitas Implementasi Pembelajaran Daring (Full Online) Dimasa Pandemi Covid-19 Pada Jenjang Sekolah Dasar Di Kabupaten Subang. Didaktik: Jurnal Ilmiah PGSD STKIP Subang, 6(1), 1-9. https://doi.org/10.36989/didaktik.v6i1.120

Hashemi, R., Moustafa, A. A., Rahmati Kankat, L., \& Valikhani, A. (2018). Mindfulness and suicide ideation in iranian cardiovascular patients: Testing the mediating role of patience. Psychological Reports, 121, 1037-1052. https://doi.org/10.1177/0033294117746990

Heslin, K. C., Elixhauser, A., \& Steiner, C. A. (2012). Hospitalizations involving mental and substance use disorders among adults, 2012 (Healthcare Cost and Utilization Project Statistical Brief \#191). Rockville, MD: Agency for Healthcare Research and Quality. Retrieved from https://www.ncbi.nlm.nih.gov/books/NBK310986/

Jamaluddin, D., Ratnasih, T., Gunawan, H., \& Paujiah, E. (2020). Pembelajaran daring masa pandemik Covid-19 pada calon guru: hambatan, solusi dan proyeksi. LP2M.

Kalloo, R. C., Mitchell, B., \& Kamalodeen, V. J. (2020). Responding to the COVID-19 pandemic in Trinidad and Tobago: challenges and opportunities for teacher education. Journal of Education for Teaching, 1-11. https://doi.org/10.1080/02607476.2020.1800407

Kar, S. K., Arafat, S. Y., Kabir, R., Sharma, P., \& Saxena, S. K. (2020). Coping with mental health challenges during COVID-19. In Coronavirus Disease 2019 (COVID-19) (pp. 199-213). Springer, Singapore. 
Kementerian Kesehatan Republik Indonesia, 2020. Pedoman Pencegahan dan Pengendalian Corona Virus Diaseases (COVID-19). Direktorat Jenderal Pencegahan dan Pengendalian Penyakit. https://COVID19.go.id/p/protokol/pedoman-pencegahan-dan-pengendalian-coronavirusdisease-COVID-19

Khasanah, D. R. A. U., Pramudibyanto, H., \& Widuroyekti, B. (2020). Pendidikan Dalam Masa Pandemi Covid-19. Jurnal https://sinestesia.pustaka.my.id/journal/article/view/44

Sinestesia, $10(1)$, 41-48.

Kurniati, E., Alfaeni, D. K. N., \& Andriani, F. (2020). Analisis Peran Orang Tua dalam Mendampingi Anak di Masa Pandemi Covid-19. Jurnal Obsesi: Jurnal Pendidikan Anak Usia Dini, 5(1), 241256. https://doi.org/10.31004/obsesi.v5i1.541

Latip, A. (2020). Peran literasi teknologi informasi dan komunikasi pada pembelajaran jarak jauh di masa pandemi Covid-19. EduTeach: Jurnal Edukasi dan Teknologi Pembelajaran, 1(2), 108-116. https://doi.org/10.37859/eduteach.v1i2.1956

Lazarus, R.S., \& Folkman, S. (1984). Stress, appraisal, and coping. New York: Springer Publishing Company, Inc.

Mercer, S. \& Gregersen, T. (2020). Teacher Well-being. Oxford University Press

Murphy, M. P. (2020). COVID-19 and emergency eLearning: Consequences of the securitization of higher education for post-pandemic pedagogy. Contemporary Security Policy. 41(3), 492505. https://doi.org/10.1080/13523260.2020.1761749.

Nasri, N. M., Husnin, H., Mahmud, S. N. D., \& Halim, L. (2020). Mitigating the COVID-19 pandemic: a snapshot from Malaysia into the coping strategies for pre-service 'teachers' $\begin{array}{lllll}\text { education. Journal of } & \text { Education } & \text { for } & \text { Teaching, } & \text { 1-8. }\end{array}$ https://doi.org/10.1080/02607476.2020.1802582

Navarrete-Mejía, P. J., Parodi, J. F., Rivera-Encinas, M. T., Runzer- Colmenares, F. M., VelascoGuerrero, J. C., \& Sullcahuaman-Valdiglesias, E. (2020). Perfil del cuidador de adulto mayor en situación de pandemia por SARS-COV-2, Lima-Perú [Profile of the elderly caregiver in a pandemic situation due to SARSCOV- 2, Lima-Peru]. Revista del Cuerpo Médico del HNAAA, 13(1), 26-23. https://doi.org/10.35434/rcmhnaaa.2020.131.596

Nayana, F. N. (2013). Kefungsian keluarga dan subjective well-being pada remaja. Jurnal Ilmiah Psikologi Terapan, 1(2), 230-244. https://doi.org/10.22219/jipt.v1i2.1580

Padli, F., \& Rusdi, R. (2020). Respon siswa dalam pembelajaran online selama pandemi. Social Landscape Journal, 1(3), 1-7. http://103.76.50.195/SLJ/article/view/14508/8524

Pangondian, R. A., Santosa, P. I., \& Nugroho, E. (2019). Faktor-Faktor Yang Mempengaruhi Kesuksesan Pembelajaran Daring Dalam Revolusi Industri 4.o. In Seminar Nasional Teknologi Komputer \& Sains (SAINTEKS). 1(1). https://www.prosiding.seminarid.com/index.php/sainteks/article/view/122

Park, C. L., Russell, B. S., Fendrich, M., Finkelstein-Fox, L., Hutchison, M., \& Becker, J. (2020).. Journal of General Internal Medicine, 'Americans' COVID-19 Stress, Coping, and Adherence to CDC Guidelines, 1. https://doi.org/10.1007/s11606-020-05898-9

Patrick, S. W., Henkhaus, L. E., Zickafoose, J. S., Lovell, K., Halvorson, A., Loch, S., Letterie, M., \& Davis, M. M. (2020). Well-being of parents and children during the COVID-19 pandemic: A national survey. Pediatrics, e2020016824. https://doi.org/d9ct

Pham, H. H., \& Ho, T. T. H. (2020). Toward a 'new 'normal'with e-learning in Vietnamese higher education during the post COVID-19 pandemic. Higher Education Research \& Development, 39(7), 1327-1331. https://doi.org/10.1080/07294360.2020.1823945

Pratiwi, N. K. (2017). Pengaruh tingkat pendidikan, perhatian orang tua, dan minat belajar siswa terhadap prestasi belajar bahasa indonesia siswa smk kesehatan di kota tangerang. Pujangga, 1(2), 31. http://dx.doi.org/10.47313/pujangga.v1i2.320

Purwanto, A., Pramono, R., Asbari, M., Hyun, C. C., Wijayanti, L. M., \& Putri, R. S. (2020). Studi eksploratif dampak pandemi COVID-19 terhadap proses pembelajaran online di sekolah dasar. EduPsyCouns: Journal of Education, Psychology and Counseling, 2(1), 1-12. https://ummaspul.e-journal.id/Edupsycouns/article/view/397

Raaper, R., \& Brown, C. (2020). The Covid-19 pandemic and the dissolution of the university campus: Implications for student support practice. Journal of Professional Capital and Community. 1-7. https://doi.org /10.1108/JPCC-06-2020-0032

Santrock, J. (2003). Adolescence. Perkembangan Remaja. (Terjemahan.). Jakarta : Erlangga. 
Sarafino, E.P., \& Smith, T.W. (2014). Health psychology: Biopsychosocial interactions. John Wiley \& Sons.

Schleicher, A. (2020, April). Education disrupted-education built. Spotlight: Quality education for all during Covid-19 crisis. OECD/HundrED Research Report \#011. Retrieved from https://hundred-cdn.s3.amazonaws.com/uploads/report/file/15/hundred_spotlight_covid19_digital.pdf

Schnitker, S. A. (2012). An examination of patience and well-being. Journal of Positive Psychology, 7, 263-280.

Shorer, M., \& Leibovich, L. (2020). Young ' 'children's emotional stress reactions during the COVID19 outbreak and their associations with parental emotion regulation and parental playfulness. Early Child Development and Care, 1-11. https://doi.org/10.1080/03004430.2020.1806830

Tang, T., Abuhmaid, A. M., Olaimat, M., Oudat, D. M., Aldhaeebi, M., \& Bamanger, E. (2020). Efficiency of flipped classroom with online-based teaching under COVID-19. Interactive Learning Environments, 1-12. https://doi.org/10.1080/10494820.2020.1817761

Tarigan, F. N., \& Hidayati, T. (2020). Membangun partisipasi orang tua dalam adaptasi ew normal. Dalam Prosiding Seminar Nasional Hasil Pengabdian, 3(1). 402-406. https://www.eprosiding.umnaw.ac.id/index.php/pengabdian/article/view/502

Umar, L. M., \& Nursalim, D. M. (2020). Studi Kepustakaan Tentang Dampak Wabah Covid-19 Terhadap Kegiatan Belajar Mengajar Pada Siswa Sekolah Dasar (Sd). Jurnal Bk Unesa, 11.

Wardani, A., \& Ayriza, Y. (2020). Analisis kendala orang tua dalam mendampingi anak belajar di rumah pada masa pandemi Covid-19. Jurnal Obsesi: jurnal Pendidikan anak usia dini, 5(1), 772-782. https://doi.org/10.31004/obsesi.v5i1.705

Weaver, J. L., \& Swank, J. M. (2020). 'Parents' Lived Experiences With the COVID-19 Pandemic. The Family Journal. https://doi.org/1066480720969194.

World Health Organization. (2020). Mental health and psychosocial considerations during the COVID-19 outbreak, March 182020 (No. WHO/2019-nCoV/MentalHealth/202O.1). World Health Organization.

Wu, Q., \& Xu, Y. (2020). Parenting stress and risk of child maltreatment during the COVID-19 pandemic: A family stress theory-informed perspective. Developmental Child Welfare. 2(3). 180-196. https://doi.org/10.1177/2516103220967937

Yulianingsih, W., Suhanadji, S., Nugroho, R., \& Mustakim, M. (2020). Keterlibatan Orangtua dalam Pendampingan Belajar Anak selama Masa Pandemi Covid-19. Jurnal Obsesi: Jurnal Pendidikan Anak Usia Dini, 5(2), 1138-1150. https://doi.org/10.31004/obsesi.v5i2.740

Zhu, X., \& Liu, J. (2020). Education in and after COVID-19: Immediate responses and long-term visions. Postdigital Science and Education, 1-5. https://doi.org/10.1007/s42438-02000126-3. 